\title{
Applied Orthogonal Experiment Design for the Optimum Extraction Conditions of High Concentration Selenium from Maifanite
}

\author{
Hailin Liao ${ }^{1,2}$, Lingfeng Jiang ${ }^{1,2}$, Chunjie Wei ${ }^{1,2}$, Hua Huang1,2, Jing Pan ${ }^{1,2}$, Chuntao Luo ${ }^{1,2}$ \\ ${ }^{1}$ Guangxi Scientific Research Centre of Traditional Chinese Medicine, Guangxi University of Chinese Medicine, Nanning, China \\ ${ }^{2}$ Key Laboratory of Generic Technology Research and Development of Traditional Chinese Drugs Pharmaceutics in Guangxi \\ Colleges and Universities, Guangxi University of Chinese Medicine, Nanning, China \\ Email: *jianglingfeng@126.com
}

How to cite this paper: Liao, H.L., Jiang, L.F., Wei, C.J., Huang, H., Pan, J. and Luo, C.T. (2017) Applied Orthogonal Experiment Design for the Optimum Extraction Conditions of High Concentration Selenium from Maifanite. Detection, 5, 1-4. https://doi.org/10.4236/detection.2017.51001

Received: January 11, 2017

Accepted: January 28, 2017

Published: January 31, 2017

Copyright $\odot 2017$ by authors and Scientific Research Publishing Inc. This work is licensed under the Creative Commons Attribution International License (CC BY 4.0).

http://creativecommons.org/licenses/by/4.0/

\begin{abstract}
In order to improve the concentration of selenium in the maifanite concentrate, the optimum experimental conditions were obtained by orthogonal experimentas follows: size of maifanite was 10 mesh, concentration of maifanite was 15 (expressed as the quality of maifanite divided by that of water), soaking time was $60 \mathrm{~min}$ at room temperature, heating temperature was $70^{\circ} \mathrm{C}$, heating time was $20 \mathrm{~min}, \mathrm{pH}$ value was 6 . Under this condition, the concentrations of each element (ppm)determined by ICP-AES were: $\mathrm{Fe} 0.099, \mathrm{Cu}$ 0.035, Mn 0.051, Zn 0.019, Se 0.028, Al 0.000.a ven in this document.
\end{abstract}

\section{Keywords}

Selenium, Maifanite, ICP-AES, Style, Styling

\section{Introduction}

Metal dyshomeostasis was one of pathological characterizations of Alzheimer's disease (AD) [1] [2] [3] [4]. Maifanite, a mineral medicine and was used in many fields for a long time in East Asia countries such as China and Japan [5] [6]. It might be the ideal metal homeostasis reagent. In our previous study, we found that maifanite could balance the dyshomeostasis of trace elements in A $\beta$-induced $\mathrm{AD}$ rats, and the trace element Se was very important, and its level in high dose maifanite group was higher than that in normal control group [7]. There has been heightened interest in the role of the trace element Se in health and neurologic disorders including AD [1].

Many mineral elements were produced after the primary maifanite mineral was immersed into water [6]. The major elements in the aqueous extract of mai- 
fanite were $\mathrm{K}, \mathrm{Na}, \mathrm{Ca}, \mathrm{Mg}, \mathrm{Sr}, \mathrm{Zn}, \mathrm{Cu}, \mathrm{Fe}, \mathrm{Mn}$ and Se etc. [4] [5] [6]. In order to improve the concentration of selenium in the maifanite concentrate, we designed the orthogonal experiments from six factors: size of maifanite, concentration of maifanite, soaking time at room temperature, heating temperature, heating time and $\mathrm{pH}$ value. The optimum dissolution conditions of maifanite were studied by using Se content as the index of dissolution performance.

\section{Experiment}

The maifanite was purchased from the Guifeng Maifanite Company in Guangxi Guiping City, China. Deionized water $(18 \mathrm{M} \Omega \mathrm{cm}$, Milli-Q gradient system, Millipore) was used throughout the experiments.

By the inductively coupled plasma-atomic emission spectroscopy (ICP-AES; IRIS Intrepid II XSP, USA Thermo Elemental), the elements $\mathrm{Fe}, \mathrm{Cu}, \mathrm{Zn}, \mathrm{Mn}, \mathrm{Se}$, and $\mathrm{Al}$ were analyzed in the optimum dissolution conditions of maifanite. The measurement conditions were $1200 \mathrm{~W}$ from the radio-frequency generator, a plasma argon flow rate of $15 \mathrm{~L} / \mathrm{min}$, a cooling gas flow of $14 \mathrm{~L} / \mathrm{min}$, a carrier gas flow of $1.0 \mathrm{~L} / \mathrm{min}$, a $20-\mu \mathrm{m}$ entrance slit, a $30-\mu \mathrm{m}$ exit slit, a height of observation of $15 \mathrm{~mm}$, and an integration time lapse of $5 \mathrm{~s}$.

Software of orthogonal designing assistant II V3.1 was used for the evaluation of the statistical experimental design. A five-level and six-factor orthogonal experiment (Table 1) was designed according to the L25-5-6 table as follow.

\section{Results}

According to the orthogonal experiment design (L25-5-6 table), twenty-five experiments should be accomplished. As shown in Table 2, the results of Se content were determined by ICP-AES in water extract of maifanite. Regarded Se content as the index of dissolution performance, the optimum dissolution conditions of maifanite were obtained as follow: size of maifanite was 10 mesh, concentration of maifanite was 15 (expressed as the quality of maifanite divided by that of water), soaking time was $60 \mathrm{~min}$ at room temperature, heating temperature was $70^{\circ} \mathrm{C}$, heating time was $20 \mathrm{~min}, \mathrm{pH}$ value was 6 . Under this condition, the concentrations of each element (ppm) determined by ICP-AES were: Fe

Table 1. Afive-level and six-factor orthogonal experiment was designed according to the L25-5-6 table by orthogonal designing assistant II V3.1.

\begin{tabular}{ccccccc}
\hline No. & 1 & 2 & 3 & 4 & 5 & 6 \\
\hline $\begin{array}{c}\text { Factor } \\
\text { name }\end{array}$ & Size/mesh & Concentration $^{1)}$ & $\begin{array}{c}\text { soaking } \\
\text { time/min }\end{array}$ & $\begin{array}{c}\text { heating } \\
\text { temperature } /{ }^{\circ} \mathrm{C}\end{array}$ & $\begin{array}{c}\text { heating } \\
\text { time/min }\end{array}$ & pH value \\
\hline level 1 & 10 & 1 & 10 & 50 & 20 & 5.00 \\
level 2 & 50 & 5 & 30 & 60 & 40 & 6.00 \\
level 3 & 100 & 10 & 60 & 70 & 60 & 7.00 \\
level 4 & 150 & 15 & 90 & 80 & 80 & 8.00 \\
level 5 & 200 & 25 & 120 & 90 & 120 & 9.00 \\
\hline
\end{tabular}

${ }^{1)}$ expressed as the quality of maifanite divided by that of water. ${ }^{2)}$ soaking time at room temperature. 
Table 2. The results of Se content were determined by ICP-AES in water extract of maifanite.

\begin{tabular}{|c|c|c|c|c|c|c|c|}
\hline column & 1 & 2 & 3 & 4 & 5 & 6 & \\
\hline $\begin{array}{l}\text { Factor } \\
\text { name }\end{array}$ & Size/mesh & Concentration $^{1)}$ & $\begin{array}{l}\text { soaking } \\
\text { time/min }{ }^{2)}\end{array}$ & $\begin{array}{c}\text { heating } \\
\text { temperature } /{ }^{\circ} \mathrm{C}\end{array}$ & $\begin{array}{l}\text { heating } \\
\text { time/min }\end{array}$ & $\mathrm{pH}$ value & Results/ppm \\
\hline experiment 1 & 1 & 1 & 1 & 1 & 1 & 1 & 0.035 \\
\hline experiment 2 & 1 & 2 & 2 & 2 & 2 & 2 & 0.022 \\
\hline experiment 3 & 1 & 3 & 3 & 3 & 3 & 3 & 0.038 \\
\hline experiment 4 & 1 & 4 & 4 & 4 & 4 & 4 & 0.036 \\
\hline experiment 5 & 1 & 5 & 5 & 5 & 5 & 5 & 0.014 \\
\hline experiment 6 & 2 & 1 & 2 & 3 & 4 & 5 & 0.031 \\
\hline experiment 7 & 2 & 2 & 3 & 4 & 5 & 1 & 0.023 \\
\hline experiment 8 & 2 & 3 & 4 & 5 & 1 & 2 & 0.026 \\
\hline experiment 9 & 2 & 4 & 5 & 1 & 2 & 3 & 0.027 \\
\hline experiment 10 & 2 & 5 & 1 & 2 & 3 & 4 & 0.025 \\
\hline experiment 11 & 3 & 1 & 3 & 5 & 2 & 4 & 0.022 \\
\hline experiment 12 & 3 & 2 & 4 & 1 & 3 & 5 & 0.019 \\
\hline experiment 13 & 3 & 3 & 5 & 2 & 4 & 1 & 0.021 \\
\hline experiment 14 & 3 & 4 & 1 & 3 & 5 & 2 & 0.019 \\
\hline experiment 15 & 3 & 5 & 2 & 4 & 1 & 3 & 0.015 \\
\hline experiment 16 & 4 & 1 & 4 & 2 & 5 & 3 & 0.027 \\
\hline experiment 17 & 4 & 2 & 5 & 3 & 1 & 4 & 0.024 \\
\hline experiment 18 & 4 & 3 & 1 & 4 & 2 & 5 & 0.022 \\
\hline experiment 19 & 4 & 4 & 2 & 5 & 3 & 1 & 0.029 \\
\hline experiment 20 & 4 & 5 & 3 & 1 & 4 & 3 & 0.027 \\
\hline experiment 21 & 5 & 1 & 5 & 4 & 3 & 2 & 0.023 \\
\hline experiment 22 & 5 & 2 & 1 & 5 & 4 & 3 & 0.026 \\
\hline experiment 23 & 5 & 3 & 2 & 1 & 5 & 4 & 0.017 \\
\hline experiment 24 & 5 & 4 & 3 & 2 & 1 & 5 & 0.038 \\
\hline experiment 25 & 5 & 5 & 4 & 3 & 2 & 1 & 0.029 \\
\hline mean value 1 & 0.029 & 0.028 & 0.025 & 0.025 & 0.028 & 0.027 & \\
\hline mean value 2 & 0.026 & 0.023 & 0.023 & 0.027 & 0.024 & 0.018 & \\
\hline mean value 3 & 0.019 & 0.025 & 0.030 & 0.028 & 0.027 & 0.032 & \\
\hline mean value 4 & 0.026 & 0.030 & 0.027 & 0.024 & 0.027 & 0.025 & \\
\hline mean value 5 & 0.027 & 0.022 & 0.022 & 0.023 & 0.020 & 0.025 & \\
\hline range & 0.010 & 0.008 & 0.008 & 0.005 & 0.008 & 0.014 & \\
\hline
\end{tabular}

${ }^{1)}$ expressed as the quality of maifanite divided by that of water. ${ }^{2)}$ soaking time at room temperature.

0.099, Cu 0.035, Mn 0.051, Zn 0.019, Se 0.028, Al 0.000.

\section{Conclusion}

According to the orthogonal experiment design, regarded Se content as the index of dissolution performance, the optimum dissolution conditions of maifanite were obtained as follows: size of maifanite was 10 mesh, concentration of maifanite was 15 (expressed as the quality of maifanite divided by that of water), soaking time was $60 \mathrm{~min}$ at room temperature, heating temperature was $70^{\circ} \mathrm{C}$, 
heating time was $20 \mathrm{~min}, \mathrm{pH}$ value was 6 . Under this condition, the concentrations of each element (ppm) determined by ICP-AES were: Fe 0.099, Cu 0.035, Mn 0.051, Zn 0.019, Se 0.028, Al 0.000 ure/K”.

\section{Acknowledgements}

This work was supported by the Sub Project of the Key Laboratory of Generic Technology Research and development of Traditional Chinese Drugs Pharmaceutics in Guangxi colleges and Universities (No. ZJGX201402005), which affiliated to Promotion Project of Science and Technology Innovation Ability in Guangxi Colleges and Universities (approved by the Education Department of Guangxi Government, China, No. [2014] 14).

\section{References}

[1] Loef, M., Schrauzer, G.N. and Walach, H. (2011) Selenium and Alzheimer's Disease: A Systematic Review. Journal of Alzheimers Disease, 26, 81-104.

[2] Ozcelik, D., Uzun, H. and Nazıroglu, M. (2012) N-Acetylcysteine Attenuates Copper Overload-Induced Oxidative Injury in Brain of Rat. Biological Trace Element Research, 147, 292-298. https://doi.org/10.1007/s12011-012-9320-1

[3] Takahashi, S., Takahashi, I., Sato, H., Kubota, Y., Yoshida, S. and Muramatsu, Y. (2001) Age-Related Changes in the Concentrations of Major and Trace Elements in the Brain of Rats and Mice. Biological Trace Element Research, 80, 145-158. https://doi.org/10.1385/BTER:80:2:145

[4] Koç, E.R., Ilhan, A., Zübeyde, A., Acar, B., Gürler, M., Altuntaş, A., Karapirli, M. and Bodur, A.S. (2015) A Comparison of Hair and Serum Trace Elements in Patients with Alzheimer Disease and Healthy Participants. Turkish Journal of Medical Sciences, 45, 1034-1039. https://doi.org/10.3906/sag-1407-67

[5] Juan, L., Zhang, P.Y., Gao, Y., Song, X.G. and Dong, J.H. (2008) Overview of Maifanshi: Its Physi-Chemical Properties and Nutritious Function in Drinking Water. Environmental Science \& Technology, 31, 63-66.

[6] Zhang, B.G. (2005) The Progress of Pharmaceutical Research on the Maifanite. Chinese Traditional Patent Medicine, 27, 1205-1208.

[7] Jiang, L.F., Liao, H.L., Huang, H.M., Zhou, L.X., Li, L., Cheng, S.X. and Du, C.Z. (2013) Potential Prevention and Treatment of Maifanite for Alzheimer's Disease Based on Behavior Test, Oxidative Stress Assay and Trace Element Analysis in Hippocampus of Abeta (25-35)-Induced AD Rats. Biological Trace Element Research, 152, 50-56. https://doi.org/10.1007/s12011-012-9590-7 
Submit or recommend next manuscript to SCIRP and we will provide best service for you:

Accepting pre-submission inquiries through Email, Facebook, LinkedIn, Twitter, etc. A wide selection of journals (inclusive of 9 subjects, more than 200 journals)

Providing 24-hour high-quality service

User-friendly online submission system

Fair and swift peer-review system

Efficient typesetting and proofreading procedure

Display of the result of downloads and visits, as well as the number of cited articles Maximum dissemination of your research work

Submit your manuscript at: http://papersubmission.scirp.org/

Or contact detection@scirp.org 